\title{
IdeAs
}

Idées d'Amériques

$15 \mid 2020$

Eau et gestion de l'eau dans les Amériques

\section{Who Fought For Water and What Did They Fight For? A Comparative Analysis of Open Water Conflicts in Four South American Countries between 2000 and 2011}

Qui s'est battu pour l'eau et pour quoi luttaient-ils? Une analyse comparative des conflits ouverts relatifs à l'eau dans quatre pays sud-américains entre 2000 et 2011

¿Quiénes lucharon por el agua y por qué lucharon? Un análisis comparativo de los conflictos abiertos relacionados con el agua en cuatro países sudamericanos entre 2000 y 2011

\section{Florence Larocque}

\section{OpenEdition \\ Journals}

Édition électronique

URL : http://journals.openedition.org/ideas/7724

DOI : 10.4000/ideas.7724

ISSN : 1950-5701

Éditeur

Institut des Amériques

Référence électronique

Florence Larocque, « Who Fought For Water and What Did They Fight For? A Comparative Analysis of Open Water Conflicts in Four South American Countries between 2000 and 2011 », IdeAs [En ligne], 15 | 2020, mis en ligne le 01 mars 2020, consulté le 25 mars 2020. URL : http:// journals.openedition.org/ideas/7724; DOI : https://doi.org/10.4000/ideas.7724

Ce document a été généré automatiquement le 25 mars 2020.

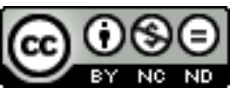

IdeAs - Idées d'Amériques est mis à disposition selon les termes de la licence Creative Commons Attribution - Pas d'Utilisation Commerciale - Pas de Modification 4.0 International. 


\section{Who Fought For Water and What Did They Fight For? A Comparative Analysis of Open Water Conflicts in Four South American Countries between 2000 and 2011}

Qui s'est battu pour l'eau et pour quoi luttaient-ils? Une analyse comparative des conflits ouverts relatifs à l'eau dans quatre pays sud-américains entre 2000 et 2011

¿Quiénes lucharon por el agua y por qué lucharon? Un análisis comparativo de los conflictos abiertos relacionados con el agua en cuatro países sudamericanos entre 2000 y 2011

Florence Larocque

1 Water and, with it, the competition for water, is a recurring and increasing source of conflicts around the world: "by 2050, global water demand is projected to increase by 55\%" (United Nations World Water Assessment Program, 2015). Latin America is no exception, and is additionally "at once the most urbanized and most unequal of the world's continents in terms of access to water" (Poupeau F. et al., 2018: 6).

Water conflicts in Latin America and elsewhere have mostly been studied by focusing on case studies or by comparing conflicts of a similar nature (privatization of water services, mining contamination, or management models of urban services) (examples include Bottaro L., Latta A. and Sola M., 2014; Akhmouch A., 2009; de Gouvello B, and Fournier J.-M., 2002; Mayaux P.-L., 2017; Spronk S., 2009; Poupeau F. et al., 2018). This article takes a different stance. Starting from the standpoint of considering water as a unique and multidimensional object of conflict, it systematically reviews all open social conflicts in which (any dimension of) water was central in four South American countries (Argentina, Chile, Bolivia and Peru), for a same period of twelve years 
(between January 2000 and December 2011). It then shows how and explores why the actors mobilizing and the dimensions of water under conflict vary overtime and between countries.

The four countries studied differed according to socio-economic development variables and their main productive industries, but also in the levels of drinking water coverage and the extent to which the sector underwent privatizing reforms. The first main contribution of the article is therefore to present the "big picture" of water conflicts that emerged in these different countries over the period of twelve years preceding the rise of "water crises" in the public and political arenas.

This overview brings readers to take a step (or a few ones) back from in-depth and detailed case studies of water conflicts. We believe this broader perspective is useful to situate the objects of these case studies, for instance to reveal how unique the water crisis in Cochabamba was and that protests for the protection of water sources from mining activities have taken place across borders. It also sheds light on the important role citizens' committees have played in the mobilization for water (beyond that of traditional social and political actors).

5 The article also contributes to the understanding of how contextual factors have influenced the emergence of water conflicts. It suggests that protests asking for an expansion of water services did not only respond to lower levels of drinking water coverage, but also to whether governments had compromised or launched political initiatives raising the expectations of the population in this respect. It also shows that social responses to privatization varied greatly, and that social protests against mining activities were not correlated with the importance of mining in the national economy.

The article proceeds as follow. The first section describes the conceptual framework of this study and the second, its methodology. The third section presents an analytical overview of water conflicts in each of the country studied: Argentina, Chile, Bolivia and Peru. The fourth section draws insights from the comparison between cases.

\section{Fighting for Water?}

7 Studying water conflicts necessarily raises the question of what "fighting for water" is. The question involves two components: water as an object and the conceptualization of conflicts.

\section{Water as a Unique and Multidimensional Object}

Two conceptualizations of water have recurrently been identified at the core of water conflicts (Barraqué B. and Zandaryaa S., 2011: 7-9; Poupeau F. et al, 2018: 20). First, considering water as an economic good and therefore through the management of water services: its public or private nature, its regulation of access, allocation and quality (Bakker K., 2007; Furlong K., 2010; Morgan B., 2011). Second, conceptualizing water as a resource with various uses (human consumption, agriculture, industry, etc.) that may compete with one another (Sosa M. and Zwarteveen M., 2012; Bottaro L., Latta A. and Sola M., 2014). Yet, the distinction between these two conceptualizations hides overlaps that are encountered in empirical cases, for instance "when poor people are not connected to water services [and] they have to take water directly from the 
resources" (Barraqué B. and S. Zandaryaa, 2011: 8) or when competing uses affect (in quality or quantity) the water sources that supply water services.

9 We consider that water is a unique object in part because it is simultaneously an economic good and a resource, but also because its unicity goes beyond this "overlapping" conceptualization. Because it is essential to life and directly impacts health, it is also "the quintessential massively consumed product, and access to water is generally perceived to be more of a "social" and "basic" service than other utility services" (Savedoff W. and P. Spiller, 1999: 6). It also has a cultural, social and spiritual dimension that is important to acknowledge (McGregor D., 2012; Yates J., Harris L. and N. Wilson, 2017; Yañez N. and S. Poats, 2007; Boelens R., Perreault T. and J. Vols, 2018). A "social imaginary" may be associated to water (Wagner J., 2012) and, for instance, E. Simmons (2016) noted that "Cochabamba water symbolized region, nation, and Andean heritage, among other things."

10 The unicity and multidimensionality of water as an object is thus inherent to the study of water conflicts. Indeed, these characteristics of water are central in the arguments developed to explain these conflicts. E. Simmons (2016) argues that threat to a "subsistence good" like water (which is not only material but also a threat to community) can foster mass mobilization around the issue; B. De Gouvello and J.-M. Fournier (2002) argue that water may be associated to games of power in a community. On the basis of this multidimensional conceptualization of water, this study overviews all social conflicts which relate to any dimension of water.

\section{What is a Water Conflict?}

11 Water conflicts have often been assimilated to "water wars," taking the form of massive and sometimes violent protests. The limitations of this perspective have been given special attention in the recent literature. Some noted that conflict related to water insecurity (for instance in the US) does not necessarily manifest through publicized protest movements polarizing the debate, and that it is also "likely to be situated within the institutions responsible for regulating the environment" (Poupeau F. et al., 2018: 7). Others directly argue: "Water control conflicts are everywhere. Disputes and struggles may occur over how water is to be used, distributed, managed, treated or talked about [...]. [...] they cannot always easily be witnessed. Water conflicts may be open and visible, but often also happen in subtler, less directly visible ways" (Boelens R., Perreault T. and J. Vols, 2018: 20).

12 Although open water conflicts are a sub-category of water conflicts, there is a great variety within this sub-category. Conflicts may involve violence or not, may be more or less massive, may happen at the local or national scale, etc. Our conceptualization of open water conflicts include any social conflict that manifests on the public sphere, no matter how they characterize regarding other criteria (number of people involved, type of actions pursued, actors' involved, etc.). 


\section{Analyzing Water Conflicts: Methodological Choices and Data}

\section{Studying Open Water Conflicts}

13 The choice to focus on open water conflicts presents both advantages and limitations. On one side, its main advantage is that it allows to take into account any social conflict somehow related to water, without pre-delimitating any policy sector, geographical region, or dimension of water. Studying open conflicts also makes it possible to have a comparable source of data for all four countries, for the whole period (see section Data Sources and Analysis).

On the other side, it neglects any water conflict that occurred behind doors, including within water institutions or "hydrocracies" (Poupeau F. et al., 2018; Molle F., Mollinga P. and P. Wester, 2009). The explanatory power of the study is also limited by the fact that negative cases (cases of non-conflict) are de facto excluded. Therefore this study cannot and does not explain why some conflicts can be prevented (if so).

\section{Case Selection}

The time period studied, between 2000 and 2011, opens with the Cochabamba Water War and closes as "water crises" started (or were about to start) rising in the public and political arenas of the four countries. These twelve years have witnessed different water reforms, policies and contexts in Latin America, and especially in the four countries studied, which combine similarities and differences at the beginning of and throughout this period.

Geographically, they all share an Andean region and have similar water poverty indexes, varying between 61 and 69 (Word Resources Institute, 2006). The four of them also present important subnational variations in the availability of water resources.

In terms of traditional variables of socio-economic development, they separated in two pairs. On one side Argentina and Chile had 2000 GDP per capita amongst the highest of the region, at respectively 8657 and 9651 (in 2010 constant US dollars) (CEPAL, 2014). In 2000 the national coverage of (at least basic) drinking water services was estimated at $96 \%$ in both countries, and that of (at least basic) sanitation was at $87 \%$ for Argentina and 92\% in Chile (WHO-UNICEF, 2019). On the other side, Bolivia and Peru had significantly lower GDPs per capita in 2000, respectively of 1612 and 3287 (in 2010 constant US dollars) (CEPAL, 2014). Their levels of coverage of (at least basic) water services were estimated to be significantly lower too, with $79 \%$ for Bolivia and $81 \%$ for Peru. The coverage levels of (at least basic) sanitation were estimated at $34 \%$ for Bolivia and $64 \%$ for Peru (WHO-UNICEF, 2019).

In terms of productive activities, the role of mining and agricultural activities in the national economies of the countries vary. In 2000, at the beginning of the period studied, the participation of mining (and careers) in the national GDP was $5.2 \%$ in Argentina, $21.7 \%$ in Chile, $11 \%$ in Bolivia, and $12.3 \%$ in Peru. As for agricultural activities, they represented $8.3 \%$ of the GDP in Argentina, 3.2\% in Chile, $11.7 \%$ in Bolivia's and $8.7 \%$ in Peru (CEPAL, 2015). The share of total land dedicated to 
agriculture also varied from $47 \%$ in Argentina, to $20 \%$ in Chile, $34 \%$ in Bolivia and $18 \%$ in Peru (FAO, 2018).

Finally, as for the privatization of water services, the countries faced four different scenarios during the period studied. Chile finalized the privatization of its urban water services over the period, and these privatizations persisted until now. Argentina, where water services had partly been privatized in the 1990s, re-nationalized some (but not all) of its water services over the period. Bolivia started the period under study with the reversal of the Cochabamba water privatization, which was followed a few years later by the reversal of the privatization of the only other water services that had been privatized, in La Paz and El Alto. Finally, Peruvian water services were essentially public for the whole period, except for the water services of Tumbes, which was privatized in 2005. The privatization of other water services has been discussed, but did not materialize.

\section{Data Sources and Analysis}

The data source for conflicts is the chronologies of social conflicts published by the Observatorio Social de América Latina of the Consejo Latinoamericano de Ciencias Sociales. They were built by an expert team in each country, on the basis of a review of national newspapers. They are currently available online through the Red de bibliotecas virtuales de ciencias sociales de América Latina y el Caribe (http://biblioteca.clacso.edu.ar).

The chronologies from January 2000 until December 2011 for all four case studies have been systematically reviewed to identify all social conflict events mentioning water. Among all of these conflicts, only the ones where water was (at least partly) the object of the conflict were kept. The classification of conflict events was done through a double review of data (either by two different persons or with a time lapse of two years between the reviews).

This similar data available from a single source for all countries offers a unique opportunity to compare water conflicts in four different countries over a same period of 12 years. One important limitation of the data is however that the data only includes open conflicts reported in newspapers. (It goes beyond the aim of this study to analyze why some open conflicts may not be reported in newspapers.)

\section{An Overview of Water Conflicts in Argentina, Chile, Bolivia and Peru, 2000-2011}

This section presents a summary of water conflicts that took place between 2000 and 2011 for each country. In total 421 water conflict events were identified and analyzed. Bolivia and Peru stand out with a significantly greater number of water conflict events (see Table 1).

Table 1 Number of Water Conflict Events by Geographic Area in Argentina, Chile, Bolivia and Peru, 2000-2011

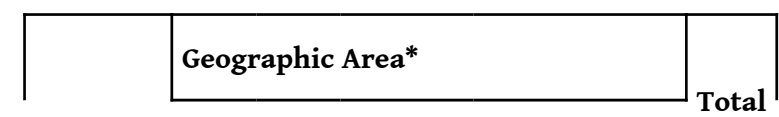




\begin{tabular}{|l|l|l|l|l|l|l|}
\cline { 2 - 6 } & Rural & Town & Periphery & Urban & National & \\
\hline Argentina & 10 & 5 & 13 & 24 & - & 52 \\
\hline Chile & 21 & 2 & - & 6 & 3 & 32 \\
\hline Bolivia & 66 & 8 & 37 & 40 & 8 & 159 \\
\hline Peru & 95 & 9 & 35 & 22 & 17 & 178 \\
\hline
\end{tabular}

* Classifications made considering: rural: settlement with less and 5000 inhabitants; town: settlement with between 25000 and 70000 inhabitants; periphery: marginal neighborhoods or informal settlements adjacent to urban areas; urban: settlement with over 100000 inhabitants; national: at least two simultaneous distant localizations.

Source: Own elaboration, based on data compiled from CLACSO chronologies (see section 2.3).

\section{Argentina} (2006), Mendoza $(2006,2009)$ and Jujuy (2011), as well as demonstrations in Buenos Aires against gold mining activities of Barrick Gold and La Alumbrera in the Andes $(2008,2010)$. As members of 86 indigenous communities 
protested against lithium mining in the province of Jujuy (2011), they also asked control over water reserves. Besides conflicts involving mining activities, environmentalists in Colonia Carlos Pellegrini (in the province of Corrientes) protested against illegal water use by the rice industry in 2010; protests also denounced the contamination of the Centro Atómico de Ezeiza (with uranium), cellulose manufactures, and sugar refineries, as well as the long-lasting contamination of the Riachuelo river and waters of Bahía Blanca.

\section{Chile}

The coalition of the Concertación was in power in Chile from 1990 until 2010. In 2000, Ricardo Lagos from the socialist party was elected president, and Michelle Bachelet (also from the socialist party) succeeded him in 2006, until 2010. Sebastián Piñera from the Alianza coalition was president between 2010 and 2014.

Water conflict events in Chile between 2000 and 2011 mostly categorize either as conflicts of uses or around the issue of water contamination. Protests related to water services were very limited, and there was only one protest asking for the nationalization of water (as part of many other claims) in 2009.

31 As for water services, the only reported protests were those of inhabitants of Temuco (2005), Pichilemu (2006) and Padre Hurtado (2008) opposing the installation of treatment plants by private providers of water services, as well as one of neighbors of Ciudad Satélite in Maipu (2011) asking that leaking water pipes of the municipal water services be repaired or replaced.

32 The conflicts over uses or rights of water were significantly more frequent. In the northern (desert) regions of the country, Aymaras protested against the reactivation of the exploitation of water sources in 2001 and to defend indigenous rights over water in 2005. Residents of San Pedro de Atacama and Alto el Loa protested against the exploitation of geothermal fields in 2006. From 2006 until 2011 (and on) mining projects in the Valle del Huasco were also protested against recurrently, because they threatened water sources (including by contaminating them). The southern regions have also been the source of water conflicts. Mapuches' organizations, as well as environmental and social ones, have protested to denounce that timber industry dry water tables and oppose various hydroelectric projects between 2005 and 2011. Mapuches also protested against water contamination due to cellulose manufactures, dumping sites and pumice industry.

\section{Bolivia}

Between 1995 and 2002, Bolivian presidents governed with "pacted democracy" coalitions that were negotiated after each election to support the elected presidency. Presidents from three traditional parties succeeded each other, and Hugo Bánzer was president from 1997 to 2002. In 2002, the traditional MNR party again got the most votes (22.9 \%), and its candidate Gonzalez Sánchez de Lozada became president. The elections nevertheless marked a significant shift, since the MAS party (led by Evo Morales) and the new NFR party (led by Manfred Reyes Villa) arrived in second and third places, both with $20.9 \%$. Within this new political setting, the Gas War irrupted in 2003, and the president resigned. His vice-president Carlos Mesa assumed presidency 
until resigning in 2005, when he was replaced by Eduardo Rodríguez Veltzé for the interim. In 2006 Evo Morales was elected president and re-elected in 2010 and 2015.

Water conflicts that took place in Bolivia between 2000 and 2011 were of course dominated by the emblematic Cochabamba Water War. Other conflicts included some that also related to the public-private management of waters, but the great majority of them rather focused on the provision of water services (mostly their expansion) or showed tensions over water uses (and contamination).

The Cochabamba Water War unfolded between January and April 2000 through numerous episodes of protests. Protesters opposed the privatization of Cochabamba water services and the hikes in consumers' rates that took effect with the private company taking over in January. From the end of March, they also manifested their opposition to Law 2029 (which was passed to ensure the legality of the contract with Aguas del Tunarí). The privatization process was finally reversed.

Around the issue of water privatization, there were protests (more limited in scope) in Potosí in 2001 to oppose a bill that could allow water mercantilization and in Tiquipaya in 2003 against the concession of drinking water services and the installation of sanitation. In 2004 and 2005 neighbors of El Alto organized various protests asking for the expulsion of the private water company; the rescission of the contract was announced by Carlos Mesa in January 2005 and officialised by Evo Morales in January 2007. Later in 2007 irrigators mobilized against the proposal to allow departmental authorities to grant concessions for the commercialization and exploitation of water.

Provision of water services has been a recurring claim over the period. In 2001 and 2005 , following the reversal of the privatization of Cochabamba water services, a few demonstrations asked for the extension of its water network in marginal neighborhoods of Cochabamba and Vinto. It is however from 2006 on that reported protests demanding provision of water services multiplied. Between 2006 and 2011 they took place across the country, in the departments of Cochabamba, La Paz, Santa Cruz, Sucre and Beni.

Whereas conflicts over water services mostly focused on asking for their expansion, neighbors and social organizations also protested to denounce the deficiencies of water services in Sucre (2001), Yacuses (2010), as well as in San Miguel de Velasco, El Alto and La Paz (2011). Besides the Cochabamba Water War, protests against increases in consumers' rates were only reported in 2011 in Santa Cruz (following the installation of water metering).

Conflicts over water uses occurred recurrently, but the competing uses varied significantly. Protests against mining activities contaminating or exploiting water were conducted by rural communities in the provinces of Quillacollo, Tacaparí and Capinota (in 2004), irrigators of Tacagua (in 2007) and indigenous peoples of ayllu Jesús de Machaca (in 2008). Water contamination with chemicals or drugs by other industries, or with sewage water also generated conflicts with communities in the departments of Cochabamba and La Paz. Among these, indigenous authorities and peasants of Laja asked for the decontamination of the Titicaca Lake in 2006 and the Agua Blanca community denounced the contamination of eternal snow (their source of water) by the cooperative Flor de Nevado in 2011.

Rural and indigenous peoples protested against hydroelectric plants and dams affecting the irrigation of their crop lands (because of too low water levels or debits) in ayllu Jila, 
Colonia Berlín, El Paso and Arbieto and Tolata (departments of Potosí, Santa Cruz and Cochabamba). In the department of Cochabamba, there have been recurrent conflicts between communities or neighbors over the use of wells since 2007. Finally, two conflicts over water uses involved transnational waters (Silala river and Madera river), for which there were negotiations between the Bolivian government and (respectively) Chile and Brazil. Labor unions, environmental organizations and local institutions (in Bolivia) also mobilized to participate in these debates.

\section{Peru}

The Peruvian president Alberto Fujimori resigned in November 2000 (in midst of a political turmoil), after a decade in power. Valentín Paniagua Corazao was then designed as the interim/ transitional president until the next election. In July 2007, the new elected president Alejandro Toledo took over. Alan García from the Partido Aprista Peruano (and former 1985-1990 president) became president in 2006 and promoted the program Agua para todos (to expand the coverage of water services).

Water conflicts that took place in Peru between 2000 and 2011 had three main purposes: asking for water provision, protecting water sources from activities damaging them, and opposing the privatization of water services or the increases in water consumers' rates. Other (less numerous) protests requested better water services.

3 Extension of water services is a recurring demand expressed in the street by communities in Peru. In 2001, 2004, 2006 and 2007 inhabitants of human settlements in the province of Lima protested to ask for services. Demonstrations on this topic intensified starting in 2008 and extended to most departments (Puno, Arequipa, Tacna, Ancash, Junín, Pasco, Trujillo, Cajamarca and Piura) by 2010. Demands for water services regularly referred to the Agua para Todos program (whether by asking for its implementation or the extension of the area covered) or to electoral promises made by local authorities.

The protection of water sources mobilized many communities across the country, and repeatedly. The contamination of waters by mining activities was by far the one denounced the most frequently: in the departments of Cajamarca (2005, 2006, 2008, 2011), Lambayeque (2005, 2009), Pasco $(2007,2008)$, Tacna (2007, 2011), Puno (2007), Ayacucho (2008), Arequipa (2008, 2009, 2010, 2011), Junín (2009), La Libertad (2010, 2011), Cuzco (2010, 2011), Moquegua (2010, 2011), Piura (2011) and Apurímac (2011). Other uses of water that were protested against included hydroelectric generation (2003, 2008, 2011), Pluspetro contaminating activities $(2006,2008,2010)$ and private uses $(2008,2009)$. There were also a few demonstrations against water contamination by sewage or used waters in Lima $(2007,2008,2009)$, Virú (2008) and Huamanga (2008).

Opposition to increases in water consumers' rates and the privatization of water services motivated many social conflicts. There were protests against rates' increases in February 2000 (ahead of the election) and the privatization of Lima's water services in May 2002, but most conflicts took place between 2005 and 2010, across the country (in Lima and in the departments of San Román, Junín, Ayacucho, Piura, Abancay, Cuzco, Apurímac, Puno and Arequipa). In most demonstrations of 2009, this opposition was directed toward the Ley de Recursos Hídricos enacted in March 2009, that promoted the participation of the private sector through its article 105. 
Finally, there were some protests (mostly in 2008) of communities asking for authorities to address the deficiencies of their water services, more specifically, unplanned interruptions, inefficient management and weak pressure.

\section{Comparative Insights on Water Conflicts}

This section compares the water conflicts reviewed over two dimensions: their protagonists and their subject.

\section{Protagonists}

In the four countries, it was reported that a range of different actors took part in the conflicts, as Table 2 summarizes. It first stands out that in Chile Indigenous communities and organizations were the most frequent protagonists (in half of all the conflict events compiled). In Bolivia and Peru, where Indigenous populations are proportionally more important, they often participated in conflicts through organizations or groups not specifically identified as Indigenous.

Table 2 Protagonists of Water Conflicts in Argentina, Chile, Bolivia and Peru, 2000-2011

\begin{tabular}{|l|l|l|l|l|l|l|}
\hline \multicolumn{7}{|l|}{ Number of Water Conflict Events in Which ... Took Part } \\
\hline & $\begin{array}{l}\text { Environmental/ } \\
\text { Social NGOs }\end{array}$ & $\begin{array}{l}\text { Labor Unions/ } \\
\text { Associations }\end{array}$ & $\begin{array}{l}\text { Politicians } \\
\text { or Parties }\end{array}$ & Indigenous & $\begin{array}{l}\text { Neighbors' } \\
\text { committees }\end{array}$ & $\begin{array}{l}\text { Issue-based } \\
\text { organization }\end{array}$ \\
\hline Argentina & 6 & 9 & 5 & 1 & 33 & 3 \\
\hline Chile & 7 & 4 & - & 16 & 11 & 7 \\
\hline Bolivia & 36 & 67 & 26 & 7 & 95 & 33 \\
\hline Peru & 41 & 45 & 19 & 10 & 96 & 48 \\
\hline
\end{tabular}

* In various water conflict events, more than one category of protagonists took part.

Source: Own elaboration, based on data compiled from CLACSO chronologies (see section Data Sources and Analysis).

A more general observation that stands out from the comparative analysis is the role played by neighbors' groups and committees. They are the type of protagonists the most (or the second-most, in the case of Chile) frequently mobilizing for water over the period. In all four countries, they are involved in more water conflict events than more traditional social and political actors (like environmental or social NGOs, labor unions and associations). Often they are mobilized without any reported alliance with other actors. This "personalized" involvement of citizens in water issues goes in line with the recent transformations of activism in general, as part of a "do-it-yourself politics" (Dufour P., Bherer L. and C. Rothmayr Allison, 2015). It would be interesting to investigate whether this is (or not) a new trend regarding water conflicts, especially given its vital (daily) necessity. Have citizens always taken a "personalized" active 
political stance regarding water or have they only recently mobilized away from social and political organizations?

\section{Subjects}

50 Whereas conflicts over uses took place in all four countries, the extent to which other subjects like drinking water coverage and privatization of water services were taken to the street differed significantly (see Table 3).

Table 3 Number of Water Conflict Events by Subject in Argentina, Chile, Bolivia and Peru, 2000-2011

\begin{tabular}{|l|l|l|l|}
\hline & $\begin{array}{l}\text { Drinking Water } \\
\text { Coverage }\end{array}$ & $\begin{array}{l}\text { Privatization of Water } \\
\text { Services }\end{array}$ & $\begin{array}{l}\text { Competing Water Uses (incl. } \\
\text { Contamination) }\end{array}$ \\
\hline Argentina & 14 & 10 & 17 \\
\hline Chile & 0 & 1 & 26 \\
\hline Bolivia & 37 & 45 & 73 \\
\hline Peru & 39 & 24 & 95 \\
\hline
\end{tabular}

Source: Own elaboration, based on data compiled from CLACSO chronologies (see section Data Sources and Analysis).

\section{Drinking Water Coverage}

One would of course expect that there would be more protests asking for water services where drinking water is not already provided to the population. Given their significantly lower drinking water coverage at the beginning of the period studied, in 2000 , it is therefore not a surprise to see that Bolivia and Peru witnessed a great number of conflicts around this issue.

Yet, the overview of conflicts in these countries does not only show that extension of water services was one of the main demands of water protests, but also that these conflicts intensified starting in 2006 in Bolivia and in 2008 in Peru. This intensification followed political commitments taken by both national governments regarding water services. In Bolivia, Evo Morales took power in 2006 and the expansion of water access was one of his political priorities (and more specifically the goal of reaching the Millennium Development Goals), as the creation of a Ministry of Water indicated. In Peru, one of the key electoral promises of Alan García in 2006 was to provide half a million people with drinking water (in six months) with the program Agua para todos. The program was created in 2007. In both cases it is after these political initiatives were launched that protests intensified, suggesting that they created expectations and that these expectations motivated communities to ask for water services. Although further research would be needed to understand the motivations of protesters, the program Agua para todos in Peru was frequently referred to after 2007 when extension for water services were claimed for, which seems to indicate that it did raise the population's expectations. 
and Argentina had very similar levels of coverage of water services in 2000: $96 \%$ nationally, which disaggregated in coverages of $99 \%$ (or more) in urban areas, and of 75 and $76 \%$ in rural areas (WHO-UNICEF, 2019). Yet, there were protests requesting drinking expansion of water services in Argentina, but not in Chile. These different political dynamics seem to be explained by a specific dimension of coverage: whether water is piped to households. $89 \%$ of Argentinian households had piped water supply, compared to $94 \%$ of Chilean ones. The difference between urban households with piped water was also significant: $94 \%$ in Argentina and $99 \%$ in Chile. In Argentina protests requesting the expansion of water services indeed took place in peripheral urban areas and, as shown in Table 1, no conflict took place in the periphery of cities in Chile.

\section{Privatization of Water Services}

Between 2000 and 2011 the privatization of water services generated various protests in Argentina, Bolivia and Peru, but only one in Chile. During this period each country was going through very different scenarios regarding the privatization of their water services.

In Argentina, the federal government had privatized the only water services under its jurisdiction (that of the capital and 13 surrounding municipalities of "Greater Buenos Aires") in 1993. Provinces (and some municipalities, where provinces had transferred them the jurisdiction in the 1980s) were encouraged to also privatize water and sanitation services: there were 12 concessions between 1991 and 2000 (Azpiazu D., Bonofiglio N. and C. Nahón, 2008; de Gouvello B., Lentini E. and F. Brenner, 2012 : 93-94; de Gouvello B., 2003; Post A., 2014).

In Chile, the privatization of urban water services took place successively in all regions, between 1993 and 2004. The first small-scale "trials of different privatization type" in 1993 in Valdivia (region XIV) and in 1995 in Litoral Sur (region V) were followed by the sale of actions of public water providers of the regions of Valparaiso, Santiago, Bío-Bío, Los Lagos, and O'Higgins between 1998 and 2000. Between 2001 and 2004, the remaining urban water services were privatized through 30-year concession contracts (Valenzuela S. and A. Jouravlev, 2007: 25; Cariola E. and M. Alegría, 2004: 76-77; Baer M., 2014).

Bolivia, water and sanitation services were conceded in three of its main cities: in La Paz and El Alto in 1997 (together in the same concession contract) and in Cochabamba in 1999 (after three calls for bids in 1996, 1998 and 1999). Both concessions were reverted: in 2000 in Cochabamba (following the emblematic Cochabamba Water War) and in 2005 in La Paz/ El Alto. (Salinas Gamarra, 2007; Nickson A. and C. Vargas, 2002; Mayaux P.-L., 2008; de Gouvello B. and Fournier J.-M., 2002).

In Peru the privatization of Lima water services was prepared for in the 1990s, but it was finally not implemented (Alcázar L., Xu L., and A. Zuluaga, 2000). Water services remained public in Peru until, in 2005, the water and sewerage services of Tumbes were conceded with a 30-year contract (which was however rescinded in 2018). The concession of the services of Piura, Huancayo, Trujillo and Pucallpa was also considered but did not go forward (Cotlear B. and C. Alza, 2010).

The conflicts reported for the four countries in relation to the privatization of water services interestingly inform the relation between social conflicts and privatization. First, protest against the privatization of water services tends to be reactive rather than proactive: it is when there is a concrete project to privatize services that 
mobilization organizes. Although that may appear obvious, it is important to note that population likely take a stance about the public or private management of water services when the consequences of privatization can be foreseen in a short-time horizon.

Second, the patterns noted in all four countries highlight that privatization does not always generate strong popular opposition and that protests against it may happen preventively or be posterior to privatization. Massive popular protests against water privatization have largely drawn scholars' attention (Simmons E., 2016; Spronk S., 2009; de Gouvello B. and J.-M. Fournier, 2002), but other privatization processes which were not strongly opposed (or were socially accepted) have been less studied. Yet, one scholar analyzing these differences between privatization responses argues that the rhythm of privatization processes plays an important role in fomenting opposition or consent when water services are privatized (Mayaux P.-L., 2017).

\section{Competing Water Uses}

61 Conflicts over water uses stand out as the type of conflicts that occurred in all four cases. The uses threatening water sources do vary between countries, but there is one constant: mining activities has generated conflicts over water sources in all four countries. Their impact on water is essentially threefold: first, a great quantity is needed for production and transport; second, processes pose risks of water contamination; third, mining activities' geographical location tend to overlap catchment areas of water sources, and glaciers (or eternal snow, which consist in water sources "for the future") (Bottaro L., Latta A. and M. Sola, 2014: 98; Sosa M. and M. Zwarteveen, 2012; Bebbington et al., 2008; Oyarzún J. and R. Oyarzún, 2011; Budds J. and L. Hinojosa, 2012).

62 The importance of mining activities for the national economy (as measured by the participation in percentage of mining in GDP) does not correlate with the number of conflicts reported. This is likely because, where mining is historically established, it is perceived as intertwined with development and faces less direct contestation (social movements rather focus on reform). Besides, at the "new frontiers of extraction," 1 where there is no strong mining tradition, there is stronger resistance (Svampa M., 2019).

63 Most protests against mining or other industrial activities for the protection of water sources mention directly superficial waters (being contaminated or diverted) or glaciers/external snows being damaged (one exception is the Mapuches protesting against the timber industry drying the water tables in Southern Chile). This observation raises a hypothesis for further research: could subterranean waters be less at risk or are they more subjected to be threatened without generating conflicts? The physical perception of the threat could be an important factor to consider; there was indeed one protest in Argentina asking for the clean-up of the Riachuelo River that involved dyeing it in green.

Finally, among the conflicts over the uses of water, some of the ones that took place in Cochabamba definitely singled out: communities or neighbors have more than once confronted each other over the use of wells. These acute conflicts certainly reveal the unique ongoing water crisis taking place in this region (for more details, see: Hines S., 2018). 


\section{Conclusion}

Argentina, Chile, Peru and Bolivia shared commonalities in the open water conflicts they faced between 2000 and 2011, but also differences. Similarities include that, in all four countries, neighbors' committees and groups took an active part in water conflicts. Mining activities frequently generated conflicts over the protection of water sources in all four countries but not the expansion of water services: the latter did so mostly when governments had created expectations about it (and where it was lacking the most). Finally, the privatization of water service was a frequent subject of conflicts in three of the four countries (not in Chile), and confrontations between neighbors over water wells were a type of conflict specific to the Cochabamba region.

The general contribution of this overview of water conflicts is mostly twofold. First, it allows to situate in a larger context the numerous in-depth studies that dig into the motivations and consequences of one or of a few water conflicts. Second, and more substantively, it offers an overview of water conflicts taking place during the period preceding the rise of "water crises" in the public and political arenas of the four countries studied. This necessary preliminary step informs and/or complements the studies analyzing how water crises unveiled in the last decade.

\section{BIBLIOGRAPHIE}

Akhmouch, Aziza, Géopolitique des privatisations: enjeux et conflits dans le secteur de l'eau et de l' assainissement en Argentine. Le cas des concessions de Santa Fe, Córdoba et Mendoza (1995-2007), PhD Thesis in Geography, Université Paris 8, 2009.

Alcázar, Lorena, Xu, Lixin Colin and Zuluaga, Ana Maria « Institutions, Politics, and Contracts: The Attempt to Privatize the Water and Sanitation Utility of Lima, Peru » World Bank Policy Research Working Paper 2478, Nov. 30, 1999, http://papers.ssrn.com/sol3/papers.cfm? abstract_id=632548. Page consulted 24 November 2010.

Azpiazu, Daniel, Bonofiglio, Nicolás and Nahón, Carolina, Agua y energía: mapa de situación y problemáticas regulatorias de los servicios públicos en el interior del país, 1st edition, Buenos Aires, Facultad Latinoamericana de Ciencias Sociales, 2008.

Baer, Madeline, « Private Water, Public Good: Water Privatization and State Capacity in Chile », Studies in Comparative International Development vol. 49, $\mathrm{n}^{\circ} 2,2014, \mathrm{p} .141-67$.

Bakker, Karen, « The 'Commons' Versus the 'Commodity': Alter-globalization, Anti-privatization and the Human Right to Water in the Global South ", Antipode, vol. 39, n 3, 2007, p.430-55.

Barraqué Bernard (ed.), Urban Water Conflicts, London, CRC Press, 2011.

Barraqué, Bernard and Zandaryaa, Sarantuyaa, « Urban water conflicts: Background and conceptual framework », in Bernard Barraqué (ed.), Urban Water Conflicts, London, CRC Press, 2011, p.1-14. 
Bebbington, Anthony, Hinojosa, Leonith, Humphreys Bebbington, Denise et al., « Contentious and ambiguity: Mining and the possibilities of development ", Development and Change, vol. $39, \mathrm{n}^{\circ} 6$, 2008, p.887-914.

Boelens, Rutgerd, Perreault, Tom and Vos, Jeroen (eds.), Water Justice, Cambridge, Cambridge University Press, 2018.

Bottaro, Lorena, Latta, Alex and Sola, Marian “La politización del agua en los conflictos por la megaminería: Discursos y resistencias en Chile y Argentina », European Review of Latin American and Caribbean Studies, $\mathrm{n}^{\circ}$ 97, 2014, p.97-115.

Budds, Jessica and Hinojosa, Leonith, « Restructuring and rescaling water governance in mining contexts: The co-production of waterscapes in Peru », Water Alternatives, vol. 5, n 1, 2012, $p$. 119-37.

Cariola, Eugenio Celedón and Alegría, María Angélica, « Análisis del proceso de privatización de los sistemas de agua potable y saneamiento urbanos en Chile », REGA-Revista de gestión del agua de América latina, vol. 1, nº 2, 2014, p.65-85.

CEPAL-Comisión Económica para América Latina y el Caribe, Estadísticas e indicadores económicos Producto interno bruto (PIB) total anual por habitante a precios constantes en dólares, 2014, http:// estadisticas.cepal.org/cepalstat/WEB_CEPALSTAT/Portada.asp. Page consulted 10 September 2015.

CEPAL-, Estadísticas e indicadores económicos - Participación en el producto interno bruto (PIB) anual por actividad económica a precios constantes, 2015. http://estadisticas.cepal.org/cepalstat/ WEB_CEPALSTAT/Portada.asp. Page consulted 10 May 2016.

Cotlear, Blanche and Alza, Carlos, « Advocacy by the Office of the Ombudsman: Enabling Water Reforms Based on Citizens' Feedback in Peru », World Bank Institute Social Accountability Notes, January 2010.

de Gouvello, Bernard, «Les multiples visages de la réorganisation des services d'eau dans les villes argentines ", in Schneier-Madanes, Graciela and de Gouvello, Bernard (eds.), Eaux et réseaux: les défis de la mondialisation, Paris, Éditions de l'IHEAL, 2003, p.235-52.

de Gouvello, Bernard and Fournier, Jean-Marc, « Résistances locales aux 'privatisations' des services de l'eau: les cas de Tucuman (Argentine) et Cochabamba (Bolivie) », Autrepart, $\mathrm{n}^{\circ} 21,2002$, p.69-82.

de Gouvello, Bernard, Lentini, Emilio J. and Brenner, Frederica, « Changing paradigms in water and sanitation services in Argentina: towards a sustainable model? » Water International, vol. 37, no 2, 2012, p.91-106.

Dufour, Pascale, Bherer, Laurence et Rothmayr Allison, Christine. 2015. « 'Faire la politique soimême' : le cas des mobilisations contre le gaz de schiste au Québec. » Revue canadienne de science politique, vol. $48, \mathrm{n}^{\circ} 1, \mathrm{p} .125-46$.

FAO-Food and Agriculture Organization of the United Nations, FAOSTAT Agri-environmental Indicators, Land Use, 2018, http://www.fao.org/faostat/en/\#data/EL. Page consulted 10 September 2019.

Furlong, Kathryn, « Neoliberal Water Management: Trends, Limitations, Reformulations », Environment and Society: Advances in Research, vol. 1, 2010, p.46-75.

Hines, Sarah T., « The Power and Ethics of Vernacular Modernism: The Misicuni Dam Project in Cochabamba, Bolivia, 1944-2016 ", Hispanic American Historical Review, vol. 98, n 2, 2018, p.223-56. 
Mayaux, Pierre-Louis. « Retour sur le retrait de Suez de La Paz-El Alto », Flux, vol.4, n 74, 2008, p. 83-91.

Mayaux, Pierre-Louis, La privatisation dans tous ses états. Protestations et consentement dans les services d'eau d'Amérique Latine, Paris, L'Harmattan, 2017.

McGregor, Deborah, « Traditional knowledge: Considerations for Protecting Water in Ontario », International Indigenous Policy Journal, vol. 3, 2012, p.1-21.

Molle, François, Mollinga, Peter P. and Wester, Philippus, « Hydraulic bureaucracies and the hydraulic mission: Flows of water, flows of power ", Water Alternatives vol. 2, n 3, 2009, p.328-49.

Morgan, Bronwen, Water on Tap. Rights and Regulation in the Transnational Governance of Urban Water Services, Cambridge, Cambridge University Press, 2011.

Nickson, Andrew and Vargas, Claudia, « The limitations of water regulation: The failure of Cochabamba concession in Bolivia », Bulletin of Latin American Research, vol. 21, $\mathrm{n}^{\circ}$ 1, 2002, p. 99-120.

Oyarzún, Jorge and Oyarzún, Ricardo, « Sustainable development threats, inter-sector conflicts and environmental policy requirements in the arid, mining rich, northern Chile territory ", Sustainable Development, vol. 19, $\mathrm{n}^{\circ} 4,2011, \mathrm{p} .263-74$.

Post, Alison E, Foreign and Domestic Investment in Argentina. The Politics of Privatized Infrastructure, New York, Cambridge University Press, 2014.

Poupeau, Franck, Razafimahefa, Lala, Robert, Jérémy, et al. Water Conflicts Hydrocracy in the Americas: Coalitions, Networks, Policies. IEE-USP, 2018, <halshs-01914315>.

Salinas Gamarra, Luis Fernando, « Reformas institucionales en los servicios de agua de La Paz y Cochabamba », in Henry Oporto and Luis Fernando Salinas (eds.), Agua y Poder. La Paz/ Washington, D.C.: Fundación Milenio/ Center for Private Enterprise, 2007, p.57-167.

Savedoff, William and Spiller, Pablo (eds.), Spilled Water: Institutional Commitment in the Provision of Water Services, Washington, DC, Inter-American Development Bank, 1999.

Simmons, Erica S., « Market Reforms and Water Wars », World Politics, vol. 68, n 1, 2016, p.37-73. Sosa, Milagros and Zwarteveen, Margreet, « Exploring the politics of water grabbing: The case of large mining operations in the Peruvian Andes », Water Alternatives, vol. 5, nº 2, 2012, p.360-75. Spronk, Susan, «Water Privatization and the Prospects for Trade Union Revitalization in the Public Sector: Case Studies From Bolivia and Peru », Just Labour: A Canadian Journal of Work and Society, vol. 14, 2009, p.164-76.

Svampa, Maristella, Neo-Extractivism in Latin America: Socio-environmental Conflicts, the Territorial Turn, and New Political Narratives, Cambridge, Cambridge University Press, 2019.

United Nations World Water Assessment Program, The United Nations World Water Development Report 2015: Water for a Sustainable World, Paris, UNESCO, 2015.

Valenzuela, Soledad and Jouravlev, Andrei. Servicios urbanos de agua potable y alcantarillado en Chile: factores determinantes de desempeño, Santiago de Chile, CEPAL, 2007.

Wagner, John R., « Water and the Commons Imaginary », Current Anthropology, vol. 53, n 5, 2012, p.617-41.

WHO-UNICEF Joint Monitoring Programme for Water Supply, Sanitation and Hygiene, Estimates on the use of water, sanitation and hygiene by country (2000-2017), 2019, http://www.washdata.org. Page consulted 10 September 2019. 
World Resources Institute, EarthTrends - Freshwater indices: Water Poverty Index, http://

earthtrends.wri.org/searchable_db/index.php?

theme=2\&variable_ID=1299\&action=select_countries. Page consulted 1st April 2006.

Yañez, Nancy and Poats, Susan (eds.), Derechos de agua y gestión ciudadana, La Paz, Plural Editores, 2007.

Yates, Julian S, Harris, Leila M. and Wilson, Nicole J., « Multiple ontologies of water: Politics, conflict and implications for governance », Environment and Planning D: Society and Space, vol. 35, $\mathrm{n}^{\circ}$ 5, 2017, p.797-815.

\section{NOTES}

1. I would like to thank one of the reviewer for suggesting this formulation.

\section{RÉSUMÉS}

Les conflits relatifs à l'eau ont surtout été étudiés en tant qu'études de cas ou en comparant des conflits sur des thématiques communes (comme la privatisation des services d'eau potable, la contamination des activités minières ou la gestion des services d'eau potable). Cet article se positionne différemment, en considérant d'emblée l'eau comme un objet à la fois unique et multidimensionnel de conflit. Il présente, d'abord, une revue des conflits sociaux ouverts relatifs à (n'importe laquelle des dimensions de) l'eau, qui ont eu lieu en Argentine, au Chili, en Bolivie et au Pérou entre janvier 2000 et décembre 2011. Cette vue d'ensemble permet de mettre en perspective les études approfondies de conflits spécifiques et l'essor des « crises hydriques » de la dernière décennie. Ensuite, cet article met en lumière comment et pourquoi les acteurs impliqués ainsi que les dimensions conflictuelles de l'eau varient dans le temps et entre les pays. L'analyse empirique repose sur une double revue systématique des chronologies des conflits sociaux publiées par l'Observatorio Social de América Latina du Consejo Latinoamericano de Ciencias Sociales (CLACSO).

Water conflicts have mostly been studied by focusing on case studies or by comparing conflicts sharing a common issue (like privatization of water services, mining contamination or management of water services). This article takes a different standpoint by at once considering water as a unique and multidimensional object of conflict. Its first main contribution is to present an overview of open social conflicts related to (any dimension of) water that took place in Argentina, Chile, Bolivia and Peru between January 2000 and December 2011. This overview is useful to put in perspective in-depth studies of specific conflicts and the rise of "water crises" in the 2010s. Second, the article contributes to the understanding of how and why the actors mobilizing and the dimensions of water under conflict vary overtime and between countries. The empirical analysis builds on a systematic double review of the chronologies of social conflicts published by the Observatorio Social de América Latina of the Consejo Latinoamericano de Ciencias Sociales (CLACSO). 
Los conflictos relacionados con el agua han sido sobre todo investigados a través de estudios de casos o de análisis comparativo de conflictos que comparten temáticas (como la privatización de los servicios de agua potable, la contaminación por las actividades mineras o la gestión de los servicios de agua). Este artículo opta por una postura distinta, al considerar de partida el agua como un objeto a la vez único y multidimensional de conflicto. Primero, presenta un panorama de los conflictos sociales abiertos relacionados con (cualquiera dimensión) del agua, los cuales tuvieron lugar en Argentina, Chile, Bolivia o Perú entre enero de 2000 y diciembre de 2011. Este panorama permite poner en perspectiva los conflictos estudiados en profundidad y el auge de las "crisis hídricas" de la última década. Segundo, este artículo evidencia cómo y porqué los actores involucrados y las dimensiones conflictivas del agua varían en el tiempo y entre los países. El análisis empírico se basa sobre una doble revisión sistemática de las cronologías de conflictos sociales publicadas por el Observatorio Social de América Latina del Consejo Latinoamericano de Ciencias Sociales (CLACSO).

\section{INDEX}

Mots-clés : eau, conflits, mobilisation sociale, Amérique du Sud, crise hydrique

Keywords : water, conflicts, mobilization, South America, water crisis

Palabras claves : agua, conflictos, movilización social, América del Sur, crisis hídrica

\section{AUTEUR}

\section{FLORENCE LAROCQUE}

Florence Larocque completed her PhD in Political Science at Columbia University in 2018. Her $\mathrm{PhD}$ thesis analyzed the reforms of drinking-water services that took place in Latin America between 1980 and 2014. She currently is a FRQSC postdoctoral fellow at the Université du Québec à Montréal and the Universidad de Chile. Her postdoctoral project studies mobilization against threats to drinking-water sources. Her research interests more generally include social policy, environmental politics, multilevel governance and political participation. Chaire de recherche en Sociologie des conflits sociaux, Université du Québec à Montréal/Instituto de Asuntos Públicos, Universidad de Chile.fl2287@columbia.edu 